\title{
Institutional interplay in global environmental governance: lessons learned and future research
}

\author{
Joshua Philipp Elsässer ${ }^{1}$ (D) - Thomas Hickmann² (Dikina Jinnah ${ }^{3}$ (D) . \\ Sebastian Oberthür ${ }^{4}$ (i) . Thijs Van de Graaf $^{5}$ (D)
}

Accepted: 5 February 2022 / Published online: 2 March 2022

(c) The Author(s) 2022

\begin{abstract}
Over the past decades, the growing proliferation of international institutions governing the global environment has impelled institutional interplay as a result of functional and normative overlap across multiple regimes. This article synthesizes primary contributions made in research on institutional interplay over the past twenty years, with particular focus on publications with International Environmental Agreements: Politics, Law and Economics. Broadening our understanding about the different types, dimensions, pathways, and effects of institutional interplay, scholars have produced key insights into the ways and means by which international institutions cooperate, manage discord, engage in problem solving, and capture synergies across levels and scales. As global environmental governance has become increasingly fragmented and complex, we recognize that recent studies have highlighted the growing interactions between transnationally operating institutions in the wake of polycentric governance and hybrid institutional complexes. However, our findings reveal that there is insufficient empirical and conceptual research to fully understand the relationship, causes, and consequences of interplay between intergovernmental and transnational institutions. Reflecting on the challenges of addressing regulatory gaps and mitigating the crisis of multilateralism, we expound the present research frontier for further advancing research on institutional interplay and provide recommendations to support policy-making.
\end{abstract}

Keywords Institutional interplay · Transnational institutional interplay · Global environmental governance $\cdot$ Transnational governance $\cdot$ Multilateral environmental agreements

Joshua Philipp Elsässer

jelsaess@uni-potsdam.de

1 Faculty of Economics and Social Sciences, University of Potsdam, August-Bebel-Straße 89, 14482 Potsdam, Germany

2 Department of Political Science, Lund University, Allhelgona kyrkogata 14, 22100 Lund, Sweden

3 Department of Environmental Studies, UC Santa Cruz, 1156 High Street, Santa Cruz, CA 95064, USA

4 Institute for European Studies, Vrije Universiteit Brussel, Boulevard de la Plaine, 1050 Brussels, Belgium

5 Faculty of Political and Social Sciences, Universiteit Gent, Universiteitstraat 8, 9000 Gent, Belgium 


\section{Introduction}

Following the growth of international environmental institutions from the 1970s, intergovernmental and transnational environmental governance has rapidly proliferated over the last few decades. As a result of this proliferation, domains of institutional competence increasingly overlap. This compounds the fragmentation and institutional complexity of global environmental governance, but also creates opportunities for productive interactions among institutions (Asselt, 2014; Biermann, Pattberg, et al., 2009a; Jinnah, 2014; Oberthür \& Stokke, 2011; van Asselt \& Zelli, 2014). Not least due to diverging economic and power-related interests, cooperation among nation states in intergovernmental institutions (encompassing international organizations, treaty-based international regimes, and more informal cooperative fora and initiatives) has fallen short in addressing even the most pressing transboundary environmental challenges, such as climate change, biodiversity loss, or land degradation (e.g., Biermann \& Pattberg, 2012; Hale et al., 2013). Solving these problems now warrants coordination across a variety of institutions featuring many actors and encompassing different levels and scales of governance. It asks for complementary action by and within institutions exhibiting overlapping jurisdictions and spanning different policy areas, involving specialized agencies, governments, and a variety of non-governmental actors from business and civil society.

As the structures of global environmental governance have grown more complex, the study of institutional interplay has expanded and matured since the early 1990s. The literature has scrutinized such interplay under different terms and employing a wealth of concepts, such as 'institutional interaction,' 'overlap,' 'interlinkages,' 'institutional management,' 'institutional fragmentation,' 'polycentric networks,' 'institutional complexes,' 'overlap management,' and 'orchestration' (e.g., Abbott et al., 2015; Biermann, Pattberg, et al., 2009a; Chambers, 2008; Hickmann et al., 2020; Jinnah, 2014; Oberthür \& Stokke, 2011; Ostrom, 2010; van Asselt, 2014; Zelli, 2011; Zelli \& van Asselt, 2013). Various research streams have investigated institutional interplay, including the study of international regimes, international organizations, and international public administration. This research has enhanced our understanding of the interplay between institutions at different levels of organization and its consequences for-among others - the effectiveness, authority, and legitimacy of global environmental governance. International Environmental Agreements: Politics, Law and Economics (INEA) has been an important forum for this discussion.

We take the occasion of this Special Issue celebrating the twentieth anniversary of INEA to review progress of research on institutional interplay in global environmental governance. We pay particular attention to research published in INEA-which is in close conversation with relevant research beyond the journal as well. Our focus is on distilling primary contributions made in research on institutional interplay as a basis for identifying remaining research gaps for further advancing this line of inquiry as well as providing recommendations to support future negotiations and policy-making. We argue that research on institutional interplay has produced key insights and tools for understanding and managing related inter-institutional mechanisms, dynamics, and effects but, importantly, still has to grasp more fully the transnational turn of global environmental governance.

We pursue our analysis in four steps. First, we offer a few conceptual and methodological clarifications for our analysis (Sect. 2). This is followed by a review of the institutional interplay literature in global environmental governance. We focus that review on three 
thematic clusters: types and dimensions, drivers and effects, and fragmentation and institutional complexity (Sect. 3). Looking back at the advancements made in the study of institutional interplay, we find that linkages involving transnational environmental institutions remains an understudied phenomenon in this literature. In this emerging field of research, we argue that increased scholarly attention is needed to enhance our understanding of how transnational institutions impact interplay dynamics, including their broader implications for global environmental governance, particularly with regards to addressing the crisis of multilateralism (Sect. 4). Finally, we synthesize our analysis and highlight potential avenues for the future study of institutional interplay (Sect. 5).

\section{Setting the stage: conceptual clarifications and methodology}

Institutional interplay broadly refers to situations in which the operation, performance, and/ or development of one institution is affected by another institution (Jinnah, 2010; Oberthür $\&$ Stokke, 2011). As noted above, scholars have studied institutional interplay using various terms and concepts, such as 'interlinkages,' 'institutional interaction,' 'orchestration,' 'overlap,' or 'fragmentation' and 'complexity.' While some of these terms are merely duplicates of the same subject matter, others have added conceptual and analytical depth and nuance. All of these terms pertain to the same field of study in the sense that they recognize that individual institutions do not exist in isolation from each other but should be studied and situated within their wider ecosystems (Abbott et al., 2016). For the purposes of this article, we employ the concept of 'institutional interplay' as an umbrella term to capture this broader field of inquiry.

The variety of different terms and concepts that relate to institutional interplay testifies to the growing scholarly interest to study the ways in which institutions interact. Within this burgeoning body of scholarship, institutional interplay has been examined through the lens of various (sub-)disciplines, including international law, public policy, international political economy, international security studies, international organizations, international public administration, and international relations theory. As one of the most dynamic areas of institutional growth in world politics, global environmental politics has served as fertile ground for exploring different kinds and effects of interactions between international institutions for over two decades (Biermann et al., 2009b; Morin et al., 2013; Oberthür \& Van de Graaf, 2020).

Across these different disciplines, research on institutional interplay has been guided by different types of research questions (normative, conceptual, theoretical, and empirical) and a wide range of epistemological and ontological approaches. Essentially, existing research can be mapped along two key dimensions (Oberthür \& Gehring, 2011). First, a distinction can be drawn between systemic approaches, which focus on the relationship among institutions, and actor-centered research strategies, which see actors as either the independent variable or the dependent variable. In other words, studies following an actorcentered research strategy either focus on ways in which actors influence the interaction of institutions, or on how actors are influenced by institutional interplay. Second, we can differentiate between approaches which focus on different units of analysis for investigating interacting institutions, ranging from dyadic relationships between two institutions to 
broader interaction settings involving several dyadic cases of interaction and/or several institutions forming institutional complexes.

In reviewing this literature, we performed a comprehensive keyword analysis of INEA publications between 2001 and 2021. ${ }^{1}$ By processing the results of our search string, we identified a total of 81 articles that have studied the interplay among international institutions in different ways. We then qualitatively coded this body of work to identify three thematic clusters and arranged contributions within those clusters chronologically, in order to trace how the academic debate in each cluster has developed over time. Although we focus on contributions from INEA, we complemented the diachronic account of the thematic clusters with key contributions from other outlets that have been in close conversation with INEA discussions of this topic.

\section{Looking back: a review of institutional interplay}

In this section, we look back and take stock of the scholarship on institutional interplay in global environmental governance, with a special focus on articles published with INEA. We identify both conceptual and empirical contributions in this area of research by systematically reviewing the literature as outlined in the previous section. Centrally, we recognize three thematic clusters of inquiry into institutional interplay, which have evolved over the past decades: (1) types and dimensions of institutional interplay; (2) pathways and effects of institutional interplay; and (3) fragmentation and institutional complexity. These categories are not entirely mutually exclusive, but contributions can typically be categorized by their primary theme of inquiry.

\subsection{Thematic cluster 1: types and dimensions of institutional interplay}

Many studies on institutional interplay have sought to identify different types and dimensions of the phenomenon by introducing a plethora of taxonomies and conceptualizations. This cluster features prominently early scholarship throughout the 1990s, which was heavily influenced by research on international regimes, as scholars started to explore the consequences of regimes beyond questions of formation and change. With the term "regime interplay," Young (1996) conceptually differentiated between embeddedness (relationship to overarching principles), nesting (relationship to broader regimes based on functional or geographical linkages), clustering (relationship to other regimes based on deliberate coordination), and overlap (relationship to other regimes due to unintentional influence) when international regimes interact.

Building on Young (1996), a very basic distinction in most studies on institutional interplay is the level or scale of social organization at which interaction occurs. A bulk of studies on institutional interplay has investigated interactions between institutions at the same level of social organization, coined "horizontal institutional interplay" (e.g., Aggarwal, 1998; Young, 1996). By and large, these studies centered on institutional interplay involving intergovernmental institutions at the international level. INEA contributions have been instrumental in furthering our understanding about the horizontal linkages between international institutions, particularly pertaining to different reform strategies, such as the intentional grouping — or "clustering" — through merging, integrating, or combining multilateral

\footnotetext{
${ }^{1}$ Our search string included the following keywords: institutional inter*; institutional link*; institutional relation*; fragment*; institutional complex*; regime complex*; regime inter*; institutional overlap*; partnership*; institutional management; polycentri*; transnational; inter-organizational; inter-agency; orchestrat*; cluster*; nest*
} 
environmental agreements (MEAs) to enhance the transparency, legitimacy, and efficiency of environmental governance (Oberthür, 2002). Other INEA articles have illuminated intricate inter-institutional relationships spanning across sectoral divides in light of overlapping jurisdictions. This includes the interplay between adjacent environmental institutions, such as the linkages between the Contention of Biological Diversity (CBD) and the United Nations Framework Convention on Climate Change (UNFCCC) on forest-related subject matters (Rosendal, 2001), but also linkages between institutions from substantially different policy arenas, for example, interactions between various multilateral trade rules and the climate regime with regard to climate-related trade measures (Stokke, 2004).

Beyond studying institutional interplay at the same level of organization, another stream of research focused on interplay across different levels and scales, coined "vertical institutional interplay" (Young, 2002). These studies focus on multi-level interactions, spanning over the international/global, regional, national, and sub-national spheres. Skjærseth (2003), for example, argued that the effectiveness of international environmental regimes is contingent on the operations of domestic political and administrative institutions for North Sea pollution management. Similarly, in the case of Arctic marine transport, niched institutions at the regional level can influence the effectiveness of the international regime in which they are situated (Stokke, 2013).

\subsection{Thematic cluster 2: pathways and effects of institutional interplay}

From the 2000s onward, studies primarily scrutinized the different drivers, pathways, and effects of the interplay between intergovernmental institutions. Scholars investigated causal relationships of institutional interplay by exploring "influence," which yielded insights into the means and conditions under which institutional interplay may occur. Building on Underdal's (2004) typology of regime effectiveness, Gehring and Oberthür (2009) developed a typology to help us better understand and analyze how and with what effects institutional interplay occurs along three dimensions: (1) output (interaction of rules and rule-making processes); (2) outcome, (interaction of group-behavior); and (3) impact (interaction of target variables of institutions).

Building on this typology, the authors conjecture four different causal mechanisms through which influence can run from a source institution to a target institution: first, $\operatorname{cog}$ nitive interaction describes influence through knowledge and ideas, which manifests as a form of inter-institutional learning. Second, interaction through commitment renders influence through normative commitments taken under one institution and affecting another institution. Both of these mechanisms operate at the output level. Third, behavioral interaction captures influence through the interconnectedness of behavior across institutional domains, which may occur if behavioral changes in the source institution impact the implementation of the target institution. Behavioral interaction operates at the outcome level. Fourth, impact-level interaction denotes influence through the interdependence of ultimate governance targets of institutions and operates at the impact level of the institutions involved (Gehring \& Oberthür, 2009; Oberthür \& Stokke, 2011, pp. 35-42). Several studies have drawn on these causal mechanisms and tested their validity for research investigating the different effects of institutional interplay (e.g., Böhmelt \& Spilker, 2016; Sanderink \& Nasiritousi, 2020).

There are also several important concepts that aim to capture different effects of institutional interplay, such as the kind of inter-institutional relationship that may result from both intentional and unintentional interplay between institutions. In this regard, a first 
wave of studies predominately investigated the negative effects of interplay, which was seen as a main cause for inter-institutional conflict. However, relevant contributions also demonstrated that institutional interplay can contribute to cooperative or synergistic interinstitutional relationships as well. This has led scholars to conceptualize and differentiate between conflictive, cooperative, benign, and synergistic interplay to apprehend its negative, positive, and/or neutral effects (Bastos Lima et al., 2017; Biermann, Pattberg, et al., 2009; King, 1997; Oberthür \& Gehring, 2006; van Asselt \& Zelli, 2014). Importantly, scholars have posited on the conditions under which such outcomes are likely, including related structural and agent-based determinants of interplay outcomes (Jinnah, 2014; Oberthür, 2009; Oberthür \& Gehring, 2006; Selin \& VanDeveer, 2003).

Research on institutional interplay has also alluded to central questions of power and domination between interacting institutions. King (2004), for instance, exposed how institutional interplay can have important implications for equity in global politics. Her exploration of vertical interplay between competing knowledge systems demonstrated how interplay between local and international institutions can promote certain knowledge systems over others. Importantly, she highlighted how this dynamic can lead to powerful international knowledge systems overriding less powerful traditional ones. Her study illuminated the mechanisms through which this occurs, especially when one institution has greater control over important regime processes, such as data collection, research agendas, and methods of information processing (King, 2004, p. 174).

Scholars have also investigated effects of institutional interplay beyond dyadic relationships. These studies have focused either on the consequences of interplay between multiple institutions that cogovern particular issue areas within overlapping jurisdictions (regime or institutional complexes) or the effects of institutional interplay on the respective overarching system of institutions for a given policy arena (governance architectures) (Alter \& Meunier, 2009; Biermann, Pattberg, et al., 2009; Biermann et al., 2010; Gehring \& Faude, 2013; Jinnah, 2011; Oberthür \& Stokke, 2011; Van de Graaf \& De Ville, 2013). By adopting such a perspective, a number of important questions have been addressed within INEA, such as whether and how institutional interplay can be strategically employed to steer environmental policy integration (e.g., Velázquez Gomar, 2016), or how and to what degree interplay can drive institutional design characteristics within regime complexes (e.g., Böhmelt \& Spilker, 2016).

Against this background, Oberthür (2009) outlined the concept of interplay management, which refers to agent-based control of inter-institutional relationships. He differentiated between four types of interplay management operating at different levels. Importantly, in investigating the options for coordinating different MEAs for enhancing environmental policy integration, he argued that actual interplay management has so far predominately promoted inter-institutional learning and assistance for the benefit of environmental institutions as well as facilitated mutual respect for specific environmental requirements toward long-term efficiency gains and an increased coherence of governance systems (Oberthür, 2009, p. 386). Although interplay management, also referred to as 'overlap management,' remains understudied to date, some scholars have begun to unpack the conditions under which non-state actors are able to effectively engage and/or exert influence in overlap management. In her analysis of secretariat influence, for example, Jinnah (2014) demonstrated that secretariats are particularly adept in managing overlapping institutions, especially when state preferences are weak and/or their expertise enjoys low substitutability. 


\subsection{Thematic cluster 3: fragmentation and institutional complexity}

Many studies of institutional interplay have also converged on the theme of increasing fragmentation and institutional complexity within global environmental governance (Biermann, Pattberg, et al., 2009; Pattberg et al., 2014; Zelli \& van Asselt, 2013). As a main driver for institutional complexity, fragmentation results from the proliferation of public and private institutions in a given policy area, which can have consequences for the effectiveness of interacting institutions due to overlapping mandates and jurisdictions. The regime complex of climate change, for example, is no longer governed exclusively by the UNFCCC as its institutional core, but also by institutions like the World Trade Organization (WTO), the UN Security Council, the International Civil Aviation Organization (ICAO), the International Maritime Organization (IMO) and many others, which are not geared toward addressing climate change as their primary governance target (Keohane \& Victor, 2011; van Asselt, 2014; van Asselt \& Zelli, 2014; Zelli, 2011). Such institutional configurations raise questions of institutional fit, if institutions face the twofold challenge of achieving a purpose within one specific organizational context, although they were originally designed for a different purpose and implemented in another organizational context (Moltke \& Mann, 2001).

The fragmentation of global environmental governance architectures can have both positive and negative effects. For example, the interplay between the WTO and multiple MEAs has stepwise generated increasingly interlocking governance structures within the regime complex of trade and the environment, which can minimize regulatory competition and inter-institutional conflict (Gehring, 2011). However, fragmentation can also have negative consequences, such as the emergence of conflicting institutional centers within regime complexes, which can hamper the formation of legally binding, internationally accepted regulation. This area of inquiry has been extensively covered by INEA contributions. The UNFCCC and International Maritime Organization (IMO), for example, have both addressed the regulation of GHG emissions from international shipping without consensus among key actors on a common approach toward resolving the problem (Hackmann, 2012). Fragmentation can also lead to coordination gaps and a lack of policy coherence. For instance, global forest management can be rendered less effective by a lack of cooperation across key sectors, such as agriculture, energy, and forestry (Kalaba et al., 2014; see also Rodríguez Fernández-Blanco et al., 2019); or expanding mandates under the REDD + mechanism causing diverging realities in different contexts across both global and local scales (Gupta et al., 2016).

As part of the debate on interplay management and in response to the increasing institutional complexity and fragmentation of global environmental governance, scholars have also discussed the formation of an overarching institutional framework as a means to improve institutional interaction, more effectively address transboundary environmental problems, and advance sustainable development (Biermann \& Bauer, 2005). While some have advocated for a new, overarching World Environment Organization (WEO) (Biermann, 2000; Charnovitz, 2005), others have been more skeptical and have instead argued for modifying existing decision-making procedures and/or institutional boundaries in order to enhance their effectiveness instead of creating new-likely dysfunctional-overarching frameworks (Oberthür \& Gehring, 2004). In this regard, UNEP was envisioned to take up a leading role in more centralized global environmental governance (Biermann, 2005; O'Neill, 2014, p. 61). However, UNEP has been widely considered as a weak international organization, as many institutional arrangements concerned with regulating environmental 
matters have become increasingly independent of UNEP over the past decades, resembling a very loosely and sometimes poorly coordinated network (Mee, 2005). Moreover, some opponents have doubted the effectiveness of a centralized overarching institutional framework to govern global environmental governance and law (Najam, 2005). Hypothesizing that global environmental law exhibits key characteristics of a complex adaptive system, some contributions have in fact recommended embracing institutional fragmentation and strengthening the self-organizing capabilities of such a system while maintaining institutional diversity (Kim \& Mackey, 2014). Initiated by the discussion of the formation of a WEO, the debate about the potential prospects of centralization versus decentralization in light of increasing fragmentation as well as reforming existing institutions in global environmental governance has continued until today, as recent studies emphasizing the vital role of UNEP as a coordinator and catalyzer for an array of MEAs have demonstrated (Ivanova, 2021).

\subsection{Studying interplay beyond intergovernmental institutions}

The studies presented in this section shaped our understanding of interplay over the past two decades, with INEA serving as a central node of knowledge development in this area. The third thematic cluster on fragmentation and institutional complexity is particularly crucial for future research on institutional interplay for several reasons.

First, most studies analyzed above focus on intergovernmental institutions, which like traditional theories of International Relations, center around states and national governments. This focus is at odds with recent studies on the fragmentation and institutional complexity of global environmental governance more broadly. This literature is increasingly focused on interactions between connected sets of rules and practices beyond those negotiated by national governments, paying particular attention to transnationally organized suband non-state actors. Second and related, global environmental governance is increasingly characterized by a proliferation of intergovernmental and transnational institutions; public and private actors and networks; and multilateral agreements, organizations, and bureaucracies, which have created new dependencies for information flows, technology, and finance. These broader inquires have paved the way for new research on institutional interplay through interdisciplinary engagement between international relations, administrative sciences, organizational research, transnational governance, and beyond. The next section identifies preliminary interventions in this new transnational turn and its implications for future research on institutional interplay in global environmental governance.

\section{The research frontier: institutional interplay and transnational environmental governance}

Studying the interplay between international institutions in transnational (environmental) governance is not an entirely new field of scholarly inquiry. However, it has enjoyed growth in recent years with an increasing number of publications and important empirical and conceptual developments - a trend which can also be recognized with studies published with 
INEA. This line of research rests on the assumption that much of global (environmental) governance is neither governed exclusively by individual institutions, nor inter-state processes within regime complexes. Rather, the architectures of many governance domains are made up of both inter-state, formal and informal transnational institutions, as well as public and private actors (Biermann \& Kim, 2020), giving rise to the notion of hybrid governance and hybrid institutional complexes (Abbott \& Faude, 2021; Kuyper et al., 2018). In this section, we point to emerging research trends and look in particular at the present research frontier for studying transnational institutional interplay ${ }^{2}$ in global environmental governance. In so doing, we point to three broader research strands that have emerged in recent years, which we consider areas that deserve particular attention in future studies on institutional interplay.

\subsection{Research strand 1: exploring the relationship between intergovernmental and transnational institutions}

Over the past few years, numerous scholars have analyzed the emergence of transnational institutions in the field of global environmental governance (e.g., Hale, 2020; Kalfagianni et al., 2020). In this context, some authors have focused on the relationship between intergovernmental institutions and the wide array of transnational initiatives. Pattberg and Stripple (2008), for example, recognized the growing importance of non-state and transnational approaches toward climate change mitigation against the background of deadlocked intergovernmental negotiations. By mapping the field of transnational climate governance, they acknowledged that the growing interlinkages within and beyond the transnational climate arena increase the complexity of the overall governance architecture. This offers "more possibilities for issues-linkages and strategic bargains" among both governments and non-state actors on the one hand, but also "increases the need for coordination among a growing number of agents in global climate governance" on the other (Pattberg \& Stripple, 2008, p. 385).This literature has continued to debate whether and how better coordination among these actors can be realized in the absence of a centralized structure of authority or compatible norms, rules, and procedures (Pattberg \& Stripple, 2008, p. 385; see also Pattberg et al., 2014).

With regard to the relationship between intergovernmental and transnational institutions, most scholars have argued that transnational initiatives, such as sharing best practices in city networks, environmental certification schemes of non-profit organizations, and corporate standard-setting to lower carbon footprints can be seen as complementary to intergovernmental institutions (Bäckstrand et al., 2017; Bansard et al., 2017; Hickmann, 2016). They have argued that transnational initiatives promote the norms and rules established through international environmental agreements and contribute to their implementation. In a similar vein, authors have examined how transnationally organized non-state actors could help strengthen the ambitions of national governments to mitigate global environmental problems within and beyond existing intergovernmental institutions (Hermwille, 2018; Moncel \& Asselt, 2012; Widerberg \& Pattberg, 2015). Focusing on the actor-relationships within international and transnational institutions, Böhmelt and Betzold (2013) illuminate how non-state actor influence manifests in intergovernmental negotiations, arguing that a high degree of access of non-governmental organizations in such negotiations increases states' ambitions under environmental agreements and enhances their willingness to cooperate for the joint implementation of such agreements.

${ }^{2}$ We define transnational institutional interplay as an interaction setting involving two or more internationally active institutions, of which at least one is considered a transnational institution. 
Another emerging stream of research has focused on ways in which international bureaucracies, such as intergovernmental treaty secretariats, play an important role in managing regime overlap across intergovernmental and transnational institutions, thereby influencing political outcomes (Biermann \& Siebenhüner, 2009; Hoch et al., 2019; Jinnah, 2010, 2014; Jinnah \& Lindsay, 2015; Skovgaard, 2017). In this context, studies have demonstrated that intergovernmental treaty secretariats can orchestrate, mobilize, and catalyze transnational initiatives to rally for more impactful intergovernmental policy-making and forge new alliances between public and private institutions to accelerate the transformation toward sustainable development (e.g., Hickmann \& Elsässer, 2020; Hickmann et al., 2019).

Other scholars have recently begun to trace different spheres affected by institutional interplay, connecting intergovernmental and transnational governance (Andonova et al., 2017; Cao \& Ward, 2017). They have investigated the pathways linking international, domestic, and non-state regulation. In the context of hazardous e-waste trade, for example, Renckens (2015), has demonstrated how non-state regulation can play an intermediary role between international and domestic levels when non-state actors act as policy entrepreneurs and bridge regulatory gaps for domestic legislation.

These important studies signal the need for increased scholarship to further develop our understanding of the relationship between intergovernmental institutions and transnational initiatives. Despite advancements made in better understanding transnational environmental governance, its institutions, and actors (e.g., Hale, 2020), there is still ample potential for fruitful engagement with the study of institutional interplay. A number of case studies indicate that some transnational initiatives operated by sub- and non-state actors may complement and synergize existing intergovernmental processes dealing with transboundary environmental problems. However, the vast majority of this research is concentrated on the policy domain of climate change. Other domains and pressing global environmental challenges have remained understudied. With regards to methodology, case studies remain the most widely used research approach to study institutional interplay in transnational environmental governance. Going forward, these could be complemented by both qualitative and quantitative studies, covering additional cases and issue areas, and employing innovative methodological approaches, such as network analysis, simulation modelling, or comparative analysis.

\subsection{Research strand 2: examining the drivers of interplay between intergovernmental and transnational institutions}

Another emergent wave of research examines the drivers and different pathways for the increasing interactions between intergovernmental institutions and transnational initiatives. Two drivers are evident and often referred to in the literature. First, the growing deterioration of the natural environment through human activity has led to substantial regulatory gaps in many domains of global environmental governance. In response to the slow, incremental progress made within intergovernmental institutions toward addressing transboundary environmental challenges, transnational institutions have evolved to provide new sets of voluntary standards in order to govern the behavior of environmental harmful industries, influence the design of renewable energy projects, or introduce private schemes for offsetting emissions (e.g., Bulkeley et al., 2014; Green \& Auld, 2017). The emergence of these new transnational initiatives has increased institutional density and resulted in new types of interactions. 
Second, different types of sub- and non-state actors have played key roles in launching various new transnational environmental initiatives. These actors have a strategic interest to connect themselves to established intergovernmental institutions in order to access funding, influence decision-making, or offer their expertise (Alter \& Meunier, 2009; Van de Graaf \& De Ville, 2013). Although many transnational initiatives seem to exist rather independently from the multilateral setting, these actors also position their own activities in ways that generate close interactions between them. Therefore, transnational institutional interplay can also have important implications for democracy and the legitimacy of global environmental governance - a particularly promising area for future research. While some scholars have raised concerns that private initiatives may undermine the democratic decision-making procedures and sovereignty of national governments (Kramarz, 2016; Partzsch, 2018), others argue that increasing civil-society involvement may in fact unsettle existing power structures and usher in a new wave of more inclusive and just international institutions (Dombrowski, 2010; Kuyper, 2013).

More research is needed on the drivers and pathways for intergovernmental-transnational interactions in global environmental governance. In particular, we do not know whether the findings from past research on the drivers for the growth of interactions between intergovernmental institutions hold for the interactions between intergovernmental institutions and transnational initiatives (e.g. regarding synergistic, cooperative, or conflictive inter-institutional relationships). In addition, we need to test existing causal mechanisms of institutional interplay (e.g. Gehring \& Oberthür's, 2009, four mechanisms for institutional interplay: cognitive interaction, behavioral interaction, interaction through commitment, or impact-level interaction) to see whether and to what extent these causal mechanisms vary in different subfields, or identify new drivers and causal pathways for the interactions between intergovernmental-transnational initiatives and institutions.

More conceptual research is also needed on the different types of transnational institutional interplay, including the factors determining which type of interplay arises in a given context and at what level and scale. In this regard, future research may revisit the concept of institutional management and its implications for transnational environmental governance. When non-governmental organizations seek to advance the implementation of intergovernmental institutions, or interplay managers within international organizations aim to influence the operations of private initiatives, we need to better understand how transnational institutional interplay can be managed by non-state actors to overcome conflicts, accelerate synergetic effects, and advance the implementation of intergovernmental institutions (Abbott \& Snidal, 2010; Orsini et al., 2013; Stokke, 2020).

\subsection{Research strand 3: understanding the consequences of the increasing interplay between intergovernmental and transnational institutions}

Finally, we need to better understand the implications of the growth of transnational initiatives for the effectiveness of existing international environmental institutions and for longterm global environmental problem solving. We point to two particularly promising areas of inquiry for future research. First, in the context of polycentric governance and the formation of hybrid institutional complexes (Abbott \& Faude, 2021; Ostrom, 2010), we urge additional research on the role transnational institutional interplay might play in mitigating the crisis of multilateralism. There is growing evidence that nation states are inadequately equipped to solve complex environmental problems through means of multilateral cooperation (Falkner, 2013, p. 252), caused in particular through the mismatch between intent and 
outcome for state-centric MEAs, due to the perpetual prioritization of state interest toward sovereignty and securitization (Fox \& Sneddon, 2007). This trend has been aggravated by the fact that multilateral institutions have been prone to changing power dynamics within international politics that have impacted their authority, legitimacy, and thus their effectiveness. There is, however, little evidence of fading nation states in the current international system as they still fulfill vital functions in international policy-making (Falkner, 2013).

From a functionalist perspective, transnational institutions and actors are presumed to advance transboundary environmental problem solving because they are well placed to strengthen weak institutions, promote inter-institutional cooperation, complement intergovernmental policy-making, or fill existing governance gaps (e.g., Abbott, 2014; Andonova et al., 2017). Indeed, some international institutions and organizations have opened up to increased non-state actor involvement, including from business actors and scientific communities (Tallberg et al., 2013). Intergovernmental treaty secretariats have also started to steer relevant sub- and non-state actors, and transnational initiatives toward compatible governance targets, thereby facilitating institutional learning effects at the international and national level (Hickmann \& Elsässer, 2020). At the same time, transnational institutions may play an important role in connecting international and national governance activities by facilitating information flow, policy diffusion, and inter-organizational learning (Cao \& Ward, 2017; Renckens, 2015). More research is needed to better understand whether and how the interactions between intergovernmental and transnational institutions-including transnationally organized actors - in hybrid regime complexes may help close governance gaps, enhance the overall effectiveness of global environmental governance, and alleviate the crisis of multilateralism.

Another of promising area of research should examine if intensified interactions between the intergovernmental, domestic, and transnational institutions may enable a synergetic division of labor and strengthen the effectiveness of global regulatory approaches (Betsill et al., 2015). While some studies indicate that the growing involvement of subnational and non-state actors can compensate for governance deficits in some instances (e.g., Chan \& Amling, 2019; Hermwille, 2018), generalizable results toward these critical questions remain inconclusive and need to be studied in more detail. In global climate governance, for example, the successful implementation of the 2015 Paris Agreement relies on transnational cooperative initiatives and sub-national and non-state actors to support and complement state-led policy-making under the UNFCCC (Chan et al., 2015; Hale, 2016; Hsu et al., 2019; Widerberg \& Stripple, 2016). However, we still do not know whether this novel approach will apply enough leverage to successfully address climate change, nor do we have clear insights into the consequences and overall effectiveness of the increasing interlinkages between intergovernmental and transnational institutions in other policy domains of global environmental governance. This developing field of study is still in at an early stage and requires further conceptual and empirical research efforts.

\section{Outlook and policy recommendations}

Celebrating the 20th anniversary of INEA, we reviewed the journal's contributions to institutional interplay, an area where INEA has been an important site of empirical and theoretical development. We identified three thematic clusters of research on institutional interplay: (1) types and dimensions; (2) pathways and effects; and (3) fragmentation and 
institutional complexity. Informed by international relations theory and a primary focus on state actors, a majority of the studies on institutional interplay have thus far centered on the interactions between intergovernmental institutions. We found this out of synch with the broader literature on global environmental governance, which is increasingly characterized by a proliferation of intergovernmental and transnational institutions as well as public and private actors, initiatives, and networks.

The research frontier for institutional interplay must more fully engage with the transnational turn in global environmental governance. We identify three emerging strands of research, which may serve as a point of departure for these inquiries. First, we need to further explore the relationship between intergovernmental and transnational institutions. Although progress has been made in mapping the links between intergovernmental and transnational institutions, we lack an in-depth understanding about the embeddedness of intergovernmental institutions with the wealth of transnational initiatives. While some studies indicate transnational initiatives and sub- and non-state actors within such initiatives may synergize intergovernmental processes, most of this research pertains to the policy domain of climate change. Other domains and pressing transboundary environmental problems remain understudied. In this context, innovative (quantitative) methodological approaches may be helpful to complement existing qualitative case studies to gain a broader perspective and new empirical insights in this area.

Second, future research should uncover drivers and different pathways for the growing interplay between intergovernmental and transnational institutions. In particular, we need to gain a better understanding about the synergistic, cooperative, or conflictive inter-institutional relationships that may results from such interplay. Moreover, it remains unclear how transnational institutions exert influence on intergovernmental decision-making or policy outcomes. Further evidence is needed about the causal pathways of transnational institutional interplay, through testing of existing mechanisms (e.g., Gehring \& Oberthür, 2009), or identifying new ones for different subfields of global environmental governance. Somewhat related are inquiries into new (or revised) conceptualizations on the different types and dimensions of transnational institutional interplay. For instance, how can institutional management in a transnational setting be employed to address conflicts or further promote synergies between interacting institutions?

Finally, in the context of polycentric governance and hybrid institutional complexes (Abbott \& Faude, 2021; Ostrom, 2010), little is known about the long-term consequences and effects of transnational versus intergovernmental institutional interplay for dealing with transboundary environmental problems as well as governance challenges. Will the growing interactions between intergovernmental and transnational institutions pave the way toward a new division of labor to increase the effectiveness of multilateral regulatory approaches or fill in the governance deficits of existing MEAs to mitigate the crisis of multilateralism? As there are apparent barriers in the way of harnessing potential synergies that may result from the interplay between international and transnational institutions, such as low ambition levels of some transnational governance initiatives or limited recognition and participation of transnational institutions in intergovernmental decision-making (e.g., Dombrowski, 2010; Hermwille, 2018; Michaelowa \& Michaelowa, 2017), structural changes within and outside UN institutions regarding the inherent design characteristics of MEAs toward a more integrated approach between transnational and international institutions may be needed. At this stage, we cannot predict whether the emergence of numerous new institutions to deal with transboundary environmental problems and the growing interlinkages between them herald a new generation of institutions built on transnational, democratic 
elements, such as a division of labor across levels and equitable stakeholder integration, or rather an opaque disorder of institutions which invite forum-shopping and free-riding.

Drawing on the lessons presented in this article, we propose a number of recommendations to provide support for policy-makers navigating current and future situations of institutional interplay in global environmental governance. Along with our research findings, these recommendations present an opportunity to make policies innovative in managing intuitional interplay and jurisdictional overlap, more effective by embracing the makeup of governance architectures in a given issue area, and more reflective of the complex and interdependent challenges presented by progressing transboundary environmental problems.

First, policy-makers would be wise to transgress thinking that past approaches solve current problems. Importantly, intergovernmental responses alone are insufficient to deal with contemporary global environmental problems. Our synthesis of the institutional interplay literature underlines that existing international institutions must evolve in order to cope with and mitigate progressing environmental destruction. Going forward, there is an imperative necessity for an integrated and coordinated approach involving a diverse set of public and private institutions and initiatives across governmental levels and spanning different policy domains.

Second, given the fast evolution of institutional interplay in the realm of global environmental politics, policy-makers need to break new ground and learn quickly. Contrary to past environmental problem solving, it has become apparent that an effective response to the most pressing global environmental problems hinges to a large extent on a division of labor between a plethora of actors operating within intergovernmental, transnational, and national institutions. Policy-makers should thus develop mechanisms to facilitate and maximize the effectiveness of these relationships.

Third, policy-makers are well advised to utilize new forms of institutional management, such as orchestration practices, developed largely around climate governance to ensure that other sidelined but clearly linked and equally devastating issues, such as biodiversity and land degradation, are not overlooked. Our findings suggest that institutional managers, for instance transnational entrepreneurs or treaty secretariats, can play a key role in navigating between the intergovernmental and transnational realms by reaching out and connecting relevant stakeholders and initiatives to address interdependencies and enter new partnerships aimed at catalyzing global efforts and institutional responses to implement MEAs.

Funding Open Access funding enabled and organized by Projekt DEAL. Joshua Philipp Elsässer gratefully acknowledges support received by the German Federal Environmental Foundation.

\section{Declarations}

Conflict of interest The authors have no financial or proprietary interests in any material discussed in this article.

Open Access This article is licensed under a Creative Commons Attribution 4.0 International License, which permits use, sharing, adaptation, distribution and reproduction in any medium or format, as long as you give appropriate credit to the original author(s) and the source, provide a link to the Creative Commons licence, and indicate if changes were made. The images or other third party material in this article are included in the article's Creative Commons licence, unless indicated otherwise in a credit line to the material. If material is not included in the article's Creative Commons licence and your intended use is not permitted by statutory regulation or exceeds the permitted use, you will need to obtain permission directly from the copyright holder. To view a copy of this licence, visit http://creativecommons.org/licenses/by/4.0/. 


\section{References}

Abbott, K. W. (2014). Strengthening the transnational regime complex for climate change. Transnational Environmental Law, 3(1), 57-88.

Abbott, K. W., \& Faude, B. (2021). Hybrid institutional complexes in global governance. The Review of International Organizations.

Abbott, K. W., Genschel, P., Snidal, D., \& Zangl, B. (Eds.). (2015). International Organizations as Orchestrators. Cambridge University Press.

Abbott, K. W., Green, J. F., \& Keohane, R. O. (2016). Organizational ecology and institutional change in global governance. International Organization, 70(2), 247-277.

Abbott, K. W., \& Snidal, D. (2010). International regulation without international government: Improving IO performance through orchestration. Review of International Organizations, 5(3), 315-344.

Aggarwal, V. K. (Ed.). (1998). Institutional designs for a complex world: Bargaining, linkages, and nesting. Cornell University Press.

Alter, K. J., \& Meunier, S. (2009). The politics of international regime complexity. Perspectives on Politics, 7(1), 13-24.

Andonova, L., Hale, T., \& Roger, C. (2017). The comparative politics of transnational climate governance. International Interactions, 43(1), 1-25.

Asselt, H. V. (2014). The fragmentation of global climate governance: Consequences and management of regime interactions. Elgar.

Bäckstrand, K., Kuyper, J. W., Linnér, B.-O., \& Lövbrand, E. (2017). Non-state actors in global climate governance: From Copenhagen to Paris and beyond. Environmental Politics, 26(4), 561-579.

Bansard, J., Pattberg, P., \& Widerberg, O. (2017). Cities to the rescue? Assessing the performance of transnational municipal networks in global climate governance. International Environmental Agreements: Politics, Law and Economics, 17(2), 229-246.

Bastos Lima, M. G., Kissinger, G., Visseren-Hamakers, I. J., Braña-Varela, J., \& Gupta, A. (2017). The sustainable development goals and REDD+: Assessing institutional interactions and the pursuit of synergies. International Environmental Agreements: Politics, Law and Economics, 17(4), 589-606.

Betsill, M., Dubash, N., Paterson, M., Asselt, H. V., Vihma, A., \& Harald, W. (2015). Building productive links between the UNFCCC and the broader global climate governance landscape. Global Environmental Politics, 15(2), 1-10.

Biermann, F. (2000). The Case for a World Environment Organization. Environment Science and Policy for Sustainable Development, 42(9), 22-31.

Biermann, F. (2005). The Rationale for a World Environment Organization. In F. Biermann \& S. Bauer (Eds.), A World Environment Organization: Solution Or Threat for Effective International Environmental Governance? (pp. 117-144). Ashgate Publishing Lim.

Biermann, F., \& Bauer, S. (2005). The Debate on a World Environment Organization: An Introduction. In F. Biermann \& S. Bauer (Eds.), A World Environment Organization: Solution or Threat for Effective International Environmental Governance? (pp. 1-23). Ashgate.

Biermann, F., \& Kim, R. E. (2020). Architectures of Earth System Governance: Setting the Stage. In F. Biermann \& R. E. Kim (Eds.), Architectures of Earth System Governance: Institutional Complexity and Structural Transformation (pp. 1-34). Cambridge University Press.

Biermann, F., \& Pattberg, P. (2012). Global Environmental Governance Revisited. In F. Biermann \& P. Pattberg (Eds.), Global Environmental Governance Reconsidered (pp. 1-23). MIT Press.

Biermann, F., Pattberg, P., van Asselt, H., \& Zelli, F. (2009). The Fragmentation of Global Governance Architectures: A Framework for Analysis. Global Environmental Politics, 9(4), 14-40.

Biermann, F., \& Siebenhüner, B. (Eds.). (2009b). Managers of Global Change: The Influence of International Environmental Bureaucracies. MIT Press.

Biermann, F., Siebenhüner, B., \& Schreyögg, A. (2009c). International Organizations in Global Environmental Governance. Routledge.

Biermann, F., Zelli, F., Pattberg, P., \& van Asselt, H. (2010). The Architecture of Global Climate Governance. In F. Biermann, P. Pattberg, \& F. Zelli (Eds.), Global Climate Governance Beyond 2012. Architecture, Agency and Adaptation (pp. 15-24). Cambridge University Press.

Böhmelt, T., \& Betzold, C. (2013). The impact of environmental interest groups in international negotiations: Do ENGOs induce stronger environmental commitments? International Environmental Agreements: Politics, Law and Economics, 13, 127-151.

Böhmelt, T., \& Spilker, G. (2016). The interaction of international institutions from a social network perspective. International Environmental Agreements: Politics, Law and Economics, 16(1), 67-89. 
Bulkeley, H., Andonova, L., Betsill, M., Compagnon, D., Hale, T., Hoffmann, M., Newell, P., Paterson, M., Roger, C., \& VanDeveer, S. D. (2014). Transnational Climate Change Governance. Cambridge University Press.

Cao, X., \& Ward, H. (2017). Transnational Climate Governance Networks and Domestic Regulatory Action. International Interactions, 43(1), 76-102.

Chambers, W. B. (2008). Interlinkages and the Effectiveness of International Environmental Agreements. United Nations University Press.

Chan, S., \& Amling, W. (2019). Does orchestration in the Global Climate Action Agenda effectively prioritize and mobilize transnational climate adaptation action? International Environmental Agreements: Politics, Law and Economics, 19(4-5), 429-446.

Chan, S., Asselt, H. V., Hale, T., Abbott, K. W., Beisheim, M., Hoffmann, M., Guy, B., Höhne, N., Hsu, A., Pattberg, P., Pauw, P., Ramstein, C., \& Widerberg, O. (2015). Reinvigorating international climate policy: A comprehensive framework for effective nonstate action. Global Policy, 6(4), 466-473.

Charnovitz, S. (2005). Toward a World Environment Organization: Reflections upon a vital debate. In F. Biermann \& S. Bauer (Eds.), A World Environment Organization: Solution or Threat for Effective International Environmental Governance? (pp. 87-115). Ashgate.

Dombrowski, K. (2010). Filling the gap? An analysis of non-governmental organizations responses to participation and representation deficits in global climate governance. International Environmental Agreements: Politics, Law and Economics, 10(4), 397-416.

Falkner, R. (Ed.). (2013). The Handbook of Global Climate and Environment Policy (1 ed.). Wiley-Blackwell.

Fox, C. A., \& Sneddon, C. (2007). Transboundary river basin agreements in the Mekong and Zambezi basins: Enhancing environmental security or securitizing the environment? International Environmental Agreements: Politics, Law and Economics, 7, 237-261.

Gehring, T. (2011). The Institutional Comples of Trade and Environment: Toward an Interlocking Governance Structure and a Division of Labour. In S. Oberthür \& O. S. Stokke (Eds.), Managing Institutional Complexity: Regime Interplay and Global Environmental Change (pp. 227-254). MIT Press.

Gehring, T., \& Faude, B. (2013). The Dynamics of Regime Complexes: Microfoundations and Systemic Effects. Global Governance: A Review of Multilateralism and International Organizations, 19(1), $119-130$.

Gehring, T., \& Oberthür, S. (2009). The Causal Mechanisms of Interaction between International Institutions. European Journal of International Relations, 15(1), 125-156.

Green, J. F., \& Auld, G. (2017). Unbundling the Regime Complex: The Effects of Private Authority. Transnational Environmental Law, 6(2), 259-284.

Gupta, A., Pistorius, T., \& Vijge, M. J. (2016). Managing Fragmentation in Global Environmental Governance: The REDD+ Partnership as Bridge Organization. International Environmental Agreements: Politics, Law and Economics, 16(3), 355-374.

Hackmann, B. (2012). Analysis of the governance architecture to regulate GHG emissions from international shipping. International Environmental Agreements: Politics, Law and Economics, 12, 85-103.

Hale, T. (2016). "All Hands on Deck": The Paris Agreement and Nonstate Climate Action. Global Environmental Politics, 16(3), 12-22.

Hale, T. (2020). Transnational Actors and Transnational Governance in Global Environmental Politics. Annual Review of Political Science, 23(1), 203-220.

Hale, T., Held, D., \& Young, K. (2013). Gridlock: Why Global Cooperation Is Failing When We Need It Most. Polity Press.

Hermwille, L. (2018). Making initiatives resonate: How can non-state initiatives advance national contributions under the UNFCCC? International Environmental Agreements: Politics, Law and Economics, $18(3), 447-466$.

Hickmann, T. (2016). Rethinking Authority in Global Climate Governance: How Transnational Climate Initiatives Relate to the International Climate Regime. Routledge.

Hickmann, T., \& Elsässer, J. P. (2020). New alliances in global environmental governance: How intergovernmental treaty secretariats interact with non-state actors to address transboundary environmental problems. International Environmental Agreements: Politics, Law and Economics, 20(3), 459-481.

Hickmann, T., van Asselt, H., Oberthür, S., Sanderink, L., Widerberg, O., \& Zelli, F. (2020). Institutional Interlinkages. In F. Biermann \& R. E. Kim (Eds.), Architectures of Earth System Governance: Institutional Complexity and Structural Transformation (pp. 119-136). Cambridge University Press.

Hickmann, T., Widerberg, O., Lederer, M., \& Pattberg, P. (2019). The United Nations Framework Convention on Climate Change Secretariat as an orchestrator in global climate policymaking. International Review of Administrative Sciences, 87(1), 21-38. 
Hoch, S., Michaelowa, A., Espelage, A., \& Weber, A.-K. (2019). Governing complexity: How can the interplay of multilateral environmental agreements be harnessed for effective international market-based climate policy instruments? International Environmental Agreements: Politics, Law and Economics, 19(6), 595-613.

Hsu, A., Höhne, N., Kuramochi, T., Roelfsema, M., Weinfurter, A., Xie, Y., Lütkehermöller, K., Chan, S., Corfee-Morlot, J., Drost, P., Faria, P., Gardiner, A., Gordon, D. J., Hale, T., Hultman, N. E., Moorhead, J., Reuvers, S., Setzer, J., Singh, N., ... Widerberg, O. (2019). A research roadmap for quantifying non-state and subnational climate mitigation action. Nature Climate Change, 9(1), 11-17.

Ivanova, M. (2021). The Untold Story of the World's Leading Environmental Institution: UNEP at Fifty. The MIT Press.

Jinnah, S. (2010). Overlap Management in the World Trade Organization: Secretariat Influence on TradeEnvironment Politics. Global Environmental Politics, 10(2), 54-79.

Jinnah, S. (2011). Marketing Linkages: Secretariat Governance of the Climate-Biodiversity Interface. Global Environmental Politics, 11(3), 23-43.

Jinnah, S. (2014). Post-Treaty Politics: Secretariat Influence in Global Environmental Governance. MIT Press.

Jinnah, S., \& Lindsay, A. (2015). Secretariat Influence on Overlap Management Politics in North America: NAFTA and the Commission for Environmental Cooperation. Review of Policy Research, 32(1), 124-145.

Kalaba, F. K., Quinn, C. H., \& Dougill, A. J. (2014). Policy coherence and interplay between Zambia's forest, energy, agricultural and climate change policies and multilateral environmental agreements. International Environmental Agreements: Politics, Law and Economics, 14(2), 181-198.

Kalfagianni, A., Partzsch, L., \& Widerberg, O. (2020). Transnational Institutions and Networks. In F. Biermann \& R. E. Kim (Eds.), Architectures of Earth System Governance: Institutional Complexity and Structural Transformation (pp. 75-96). Cambridge University Press.

Keohane, R. O., \& Victor, D. G. (2011). The Regime Complex for Climate Change. Perspectives on Politics, 9(1), 7-23.

Kim, R. E., \& Mackey, B. (2014). International environmental law as a complex adaptive system. International Environmental Agreements: Politics, Law and Economics, 14, 5-24.

King, L. (2004). Competing Knowledge Systems in the Management of Fish and Forests in the Pacific Northwest. International Environmental Agreements: Politics, Law and Economics, 4, 161-177.

King, L. A. (1997). Institutional Interplay: Research Questions. Institutional Dimensions of Global Environmental Change Project.

Kramarz, T. (2016). World Bank Partnerships and the Promise of Democratic Governance. Environmental Policy and Governance, 26(1), 3-15.

Kuyper, J. W. (2013). Global democratization and international regime complexity. European Journal of International Relations, 20(3), 620-646.

Kuyper, J. W., Linnér, B.-O., \& Schroeder, H. (2018). Non-state actors in hybrid global climate governance: justice, legitimacy, and effectiveness in a post-Paris era. WIREs Climate Change, 9(1), e497.

Mee, L. D. (2005). The Role of UNEP and UNDP in Multilateral Environmental Agreements. International Environmental Agreements: Politics, Law and Economics, 5, 227-263.

Michaelowa, K., \& Michaelowa, A. (2017). Transnational Climate Governance Initiatives: Designed for Effective Climate Change Mitigation? International Interactions, 43(1), 129-155.

Moltke, K., \& v., \& Mann, H. (2001). Misappropriation of Institutions: Some Lessons from the Environmental Dimension of the NAFTA Investor-State Dispute Settlement Process. International Environmental Agreements: Politics, Law and Economics, 1, 103-119.

Moncel, R., Asselt, H., \& v. (2012). All Hand on Deck! Mobilizing Climate Change Action Beyond the UNFCCC. Review of European Community \& International Environmental Law, 21(3), 163-176.

Morin, J.-F., Orsini, A., Trudeau, H., Duplessis, I., Lalonde, S., Van de Graaf, T., De Ville, F., O’Neill, K., Roger, C., Dauvergne, P., Oberthür, S., Biermann, F., Ohta, H., \& Ishii, A. (2013). Insights from Global Environmental Governance. International Studies Review, 15(4), 562-589.

Najam, A. (2005). Neither Necessary, Nor Sufficient: Why Organizational Tinkering Will Not Improve Environmental Governance. In F. Biermann \& S. Bauer (Eds.), A World Environment Organization. Solution or Threat for Effective Environmental Governance (pp. 235-256). Ashgate.

O’Neill, K. (2014). Introduction: The Environment and International Relations. Cambridge University Press.

Oberthür, S. (2002). Clustering of Multilateral Environmental Agreements: Potentials and Limitations. International Environmental Agreements: Politics, Law and Economics, 2, 317-340. 
Oberthür, S. (2009). Interplay management: Enhancing environmental policy integration among international institutions. International Environmental Agreements: Politics, Law and Economics, 9, 371-391.

Oberthür, S., \& Gehring, T. (2004). Reforming International Environmental Governance: An Institutionalist Critique of the Proposal for a World Environment Organisation. International Environmental Agreements: Politics, Law and Economics, 4(4), 359-381.

Oberthür, S., \& Gehring, T. (Eds.). (2006). Institutional Interaction in Global Environmental Governance: Synergy and Conflict among International and EU Policies. MIT Press.

Oberthür, S., \& Gehring, T. (2011). Institutional Interaction: Ten Years of Scholarly Development. In S. Oberthür \& O. S. Stokke (Eds.), Managing Instiutional Complexity: Regime Interplay and Global Environmental Change (pp. 25-58). MIT Press.

Oberthür, S., \& Stokke, O. S. (Eds.). (2011). Managing Institutional Complexity: Regime Interplay and Global Environmental Change. MIT Press.

Oberthür, S., \& Van de Graaf, T. (2020). Institutional Interactions. In J.-F. Morin \& A. Orsini (Eds.), Essential Concepts of Global Environmental Governance (2 ed., pp. 132-134). Routledge.

Orsini, A., Morin, J.-F., \& Young, O. R. (2013). Regime Complexes: A Buzz, a Boom or a Boost for Global Governance? Global Governance, 19(1), 27-39.

Ostrom, E. (2010). Polycentric Systems for Coping with Collective Action and Global Environmental Change. Global Environmental Change, 20(4), 550-557.

Partzsch, L. (2018). Take Action Now: The Legitimacy of Celebrity Power in International Relations. Global Governance: A Review of Multilateralism and International Organizations, 24(2), 229-248.

Pattberg, P., \& Stripple, J. (2008). Beyond the Public and Private Divide: Remapping Transnational Climate Governance in the 21st Century. International Environmental Agreements: Politics, Law and Economics, 8(4), 367-388.

Pattberg, P., Widerberg, O., Isailovic, M., \& Dias Guerra, F. (2014). Mapping and Measuring Fragmentation in Global Governance Architectures: A Framework for Analysis. https://ssrn.com/abstract= 2484513

Renckens, S. (2015). The Basel Convention, US politics, and the emergence of non-state e-waste recycling certification. International Environmental Agreements: Politics, Law and Economics, 15, 141-158.

Rodríguez Fernández-Blanco, C., Burns, S. L., \& Giessen, L. (2019). Mapping the fragmentation of the international forest regime complex: Institutional elements, conflicts and synergies. International Environmental Agreements: Politics, Law and Economics, 19(2), 187-205.

Rosendal, G. K. (2001). Overlapping International Regimes: The Case of the Intergovernmental Forum on Forests (IFF) between Climate Change and Biodiversity. International Environmental Agreements: Politics, Law and Economics, 1(4), 447-468.

Sanderink, L., \& Nasiritousi, N. (2020). How institutional interactions can strengthen effectiveness: The case of multi-stakeholder partnerships for renewable energy. Energy Policy, 141, 111447.

Selin, H., \& VanDeveer, S. D. (2003). Mapping Institutional Linkages in European Air Pollution Politics. Global Environmental Politics, 3(3), 14-46.

Skjærseth, J. B. (2003). Managing North Sea Pollution Effectively: Linking International and Domestic Institutions. International Environmental Agreements: Politics, Law and Economics, 3(2), 167-190.

Skovgaard, J. (2017). The devil lies in the definition: Competing approaches to fossil fuel subsidies at the IMF and the OECD. International Environmental Agreements: Politics, Law and Economics, 17(3), 341-353.

Stokke, O. S. (2004). Trade Measures and Climate Compliance: Institutional Interplay Between WTO and the Marrakesh Accords. International Environmental Agreements: Politics, Law and Economics, 4, 339-357.

Stokke, O. S. (2013). Regime interplay in Arctic shipping governance: Explaining regional niche selection. International Environmental Agreements: Politics, Law and Economics, 13, 65-85.

Stokke, O. S. (2020). Interplay Management. In F. Biermann \& R. E. Kim (Eds.), Architectures of Earth System Governance: Institutional Complexity and Structural Transformation (pp. 207-232). Cambridge University Press.

Tallberg, J., Sommerer, T., \& Squatrito, T. (2013). The Opening Up of International Organizations: Transnational Access in Global Governance. Cambridge University Press.

Underdal, A. (2004). Methodological Challenges in the Study of Regime Effectiveness. In A. Underdal \& O. R. Young (Eds.), Regime Consequences: Methodological Challenges and Research Strategies (pp. 27-48). Kluwer.

van Asselt, H. (2014). The Fragmentation of Global Climate Governance: Consequences and Management of Regime Interactions. Edward Elgar. 
van Asselt, H., \& Zelli, F. (2014). Connect the Dots: Managing the Fragmentation of Global Climate Governance. Environmental Economics and Policy Studies, 16(2), 137-155.

Van de Graaf, T., \& De Ville, F. (2013). Regime Complexes and Interplay Management. International Studies Review, 15(4), 568-571.

Velázquez Gomar, J. O. (2016). Environmental policy integration among multilateral environmental agreements: The case of biodiversity. International Environmental Agreements: Politics, Law and Economics, 16(4), 525-541.

Widerberg, O., \& Pattberg, P. (2015). International Cooperative Initiatives in Global Climate Governance: Raising the Ambition Level or Delegitimizing the UNFCCC? Global Policy, 6(1), 45-56.

Widerberg, O., \& Stripple, J. (2016). The Expanding Field of Cooperative Initiatives for Decarbonization: A Review of Five Databases. Wiley Interdisciplinary Reviews: Climate Change, 7(4), 486-500.

Young, O. R. (1996). Institutional Linkages in International Society: Polar Perspectives. Global Governance, 2(1), 1-24.

Young, O. R. (2002). The Institutional Dimensions of Environmental Change: Fit, Interplay, and Scale. MIT Press.

Zelli, F. (2011). The Fragmentation of the Global Climate Governance Architecture. Wiley Interdisciplinary Reviews: Climate Change, 2(2), 255-270.

Zelli, F., \& van Asselt, H. (2013). Introduction: The Institutional Fragmentation of Global Environmental Governance: Causes, Consequences, and Responses. Global Environmental Politics, 13(3), 1-13.

Publisher's Note Springer Nature remains neutral with regard to jurisdictional claims in published maps and institutional affiliations. 